\title{
ANALISIS PENGARUH TRANSMISI MOBIL MANUAL DAN OTOMATIS TERHADAP TINGKAT KESULITAN YANG DIHADAPI PENGEMUDI PEMULA
}

\author{
Novie Susanto*), Ratna Purwaningsih, Iqbal Adnan Baharullah \\ Departemen Teknik Industri, Fakultas Teknik, Universitas Diponegoro, \\ Jl. Prof. Soedarto, SH, Kampus Undip Tembalang, Semarang, Indonesia 50275
}

(Received: June 26, 2017/ Accepted: 22 September, 2017)

\begin{abstract}
Abstrak
Mobil yang beredar di pasaran memiliki dua sistem transmisi yang berbeda, yaitu transmisi manual dan otomatis. Pengoperasian dua transmisi tersebut tentunya berbeda secara teknis. Pengoperasian yang salah dapat menyebabkan terjadinya kecelakaan lalu lintas. Penelitian ini bertujuan untuk memberikan rekomendasi strategi khususnya bagi pengemudi pemula berkaitan dengan transmisi yang lebih mudah dalam tahap pembelajaran sehingga dapat meminimalisir resiko terjadinya kecelakaan lalu lintas. Penelitian dilakukan dengan menggunakan simulator mengemudi dengan 8 responden. Pengukuran dikhususkan pada perhitungan error, waktu mengemudi, dan terjadinya kegagalan mengemudi dengan kondisi yang telah ditentukan. Hasil penelitian yang didapatkan dari 6 perlakuan menunjukan bahwa kesalahan yang terjadi pada transmisi otomatis lebih sedikit dibandingkan dengan transmisi manual. Umumnya kesalahan yang terjadi pada kedua transmisi merupakan pelanggaran batas kecepatan dan marka jalan. Transmisi manual secara teknis lebih sulit dioperasikan. Penggunaan kopling dan hand rem yang tidak tepat justru membahayakan pengemudi pemula. Transmisi otomatis dinilai lebih baik dalam meningkatkan keamanan berkendara bagi pengemudi pemula, dikarenakan atensi yang terbagi saat mengemudi lebih sedikit dibandingkan dengan transmisi manual.
\end{abstract}

Kata kunci: Transmisi, Error, Waktu Mengemudi, Kegagalan Mengemudi, Pemula

\begin{abstract}
[Analysis of Manual And Otomatic Transmission on the Level of the Difficulties Encoutered The Novice Driver] Cars on the market has two different transmission systems, namely manual and automatic transmission. Operation of the two transmissions are different technically. A wrong operation may lead to traffic accidents. This paper presents a strategy, especially for the novice driver with regard to experience an easier learning phase so as to minimize the risk of traffic accidents. An experiment using a driving simulator with 8 respondents is taken into account. Measurements are devoted from the calculation error, driving time, and the failure of driving with a predetermined condition. The results from 6 treatments show that the error occurred in the automatic transmission is less than with a manual transmission. Generally, errors that occur in both the transmission are violation of the speed limit and road markings. The manual transmission is technically more difficult to operate. It uses the clutch and hand brake that if it used unappropriately, it will jeopardize the novice driver. The automatic transmission is considered better in improving road safety for novice drivers, because it contains a less divided attention while driving compared with the manual transmission.
\end{abstract}

Keywords: Transmission, Error, Driving time, Driving Failure, Novice.

\section{Pendahuluan}

Mengemudi merupakan aktivitas sehari-hari yang memerlukan keterampilan dan proses belajar. Beberapa

*) Penulis Korespondensi. email: novie.susanto@ft.undip.ac.id studi terkait perilaku mengemudi menyebutkan bahwa aktivitas mengemudi memiliki risiko yang besar terkait keamanan pengemudi dan lingkungan jalan raya (Hale 
dan Glendon, 1987; Daryanto, 2001; Beirness dkk., 2002).

Di Indonesia sendiri terdapat dua jenis transmisi yang paling banyak digunakan yaitu Manual dan Otomatis. Menurut Mogre (2012), transmisi manual merupakan sebuah sistem perpindahan percepatan yang menggunakan bantuan tuas transmisi. Terdiri dari gigi paling rendah 1 sampai yang paling tinggi 5-6, serta gigi atret untuk membuat mobil berjalan mundur, untuk melakukan perpindahan kecepatan pada transmisi manual dibutuhkan bantuan kopling. Transmisi otomatis adalah transmisi yang melakukan perpindahan gigi percepatan secara otomatis berdasarkan beban mesin (besarnya penekanan pedal gas) dan kecepatan kendaraan, tanpa menggunakan bantuan kopling, hasilnya transmisi otomatis menghasilkan akselerasi yang lebih rendah dibanding transmisi manual. Perbedaan transmisi manual dan otomatis dapat dilihat pada Tabel 1 .

Tabel 1. Indikator Pembeda Transmisi Manual dan Otomatis (Otonity, 2015)

\begin{tabular}{cll}
\hline Indikator Pembeda & \multicolumn{1}{c}{ Mobil Transmisi Manual } & \multicolumn{1}{c}{ Mobil Transmisi Otomatis } \\
\hline \multirow{2}{*}{ Alat kontrol utama } & Kopling & Setir \\
\cline { 2 - 3 } & Setir & Tuas perseneling \\
\cline { 2 - 3 } & Pedal Gas & Pedal gas \\
\cline { 2 - 3 } & Pedal rem & Pedal rem \\
\cline { 2 - 3 } & Hand rem & Hand rem \\
\hline Pengoperasian & Menggunakan kunci & Menggunakan kunci + menginjak pedal rem \\
\hline Start up & $\begin{array}{l}\text { Mengunakan handle perseneling }+ \\
\text { menginjak kopling }\end{array}$ & Berpindah secara otomatis \\
\hline transmisi & Menggunakan teknik setengah kopling & Menginjak pedal gas \\
\hline Jalan tanjakan & Menggunakan teknik engine break & Menginjak pedal rem \\
\hline Palan turunan & Menginjak pedal rem + pedal kopling & Menginjak pedal rem \\
\hline Performa & & \\
\hline Akselerasi & Responsif & Kurang reponsif \\
\hline Pengereman & Halus (tidak ada efek tenanga terbuang) & Sedikit tersendat \\
\hline
\end{tabular}

Menurut Otonity (2015), pengemudi pemula sebaiknya belajar menggunakan mobil otomatis terlebih dahulu karena dianggap lebih mudah dan praktis, ungkapan tersebut memang benar dikarenakan mobil otomatis memiliki cara kerja lebih simpel dibanding manual sehingga lebih mempermudah pemula dalam melakukan kinerja kaki maupun tangan dalam mengemudi. Berbeda dengan mobil transmsi manual yang lebih sulit pengoperasianya dikarenakan ada beberapa kegiatan yang harus dikerjakan secara bersamaan, sehingga berdampak pada berkurangnya konsentrasi saat mengemudi.

Lim (2009) dalam bukunya Safety Driving Guidance Book mengemukakan, safety driving merupakan sebuah pengetahuan yang wajib diketahui oleh para pengguna lalu lintas, terjadinya banyak pelanggaran serta kecelakaan membuktikan banyak orang yang belum mengetahui pentingnya hal ini. Safety Driving atau mengemudi dengan selamat adalah cara mengemudi yang benar, dengan mengetahui teknik mengemudi yang tepat, mau memahami dan mengikuti peraturan lalu lintas, sehingga dalam berkendara akan selalu aman dan selamat. Beberapa penelitian terkait perbedaan transmisi dalam mengemudi juga telah dibahas oleh Piersma dan De Waad (2007) dan Falkmer dkk (2008).

Dalam penelitian ini, safety driving berarti responden dapat mengemudi dengan aman menggunakan simulator dengan kondisi yang akan disesuaikan, ukuran aman tersebut adalah dengan minimalnya jumlah kegagalan mengemudi dan error (responden melanggar peraturan lalu lintas, seperti melebihi batas kecepatan, menerobos traffic light, menyalip kendaraan lain tidak sesuai aturan).

Setiap transmisi memiliki kelebihan dan kekuranganya masing-masing, dan pengemudi dituntut selalu siap untuk mengahadapai kondisi apapun di jalan raya. Tentunya kemampuan mengemudi setiap orang berbeda-beda dan penelitian ini bertujuan untuk menganalisis tingkat kesulitan menggunakan mobil 
dengan transmisi yang berbeda terkait keamanan mengemudi khususnya pada pengemudi di tahap belajar.

\section{Metode Penelitian}

Penelitian ini berfokus untuk membandingkan dua jenis penggunaan mobil antara menggunakan transmisi manual dengan transmisi otomatis pada seorang pengemudi pemula berkaitan dengan kesulitan yang dihadapi. Simulasi dilakukan dengan menggunakan software Euro Truck Simulator dengan perlengkapan opsi manual 6 percepatan, otomatis, paddle shift, paddle set, streetwheel set, jok pengemudi, dan 3 buah TV LCD sebagai gambaran visual. Simulator yang dipakai dalam penelitian dapat diilustrasikan seperti gambar 1 .

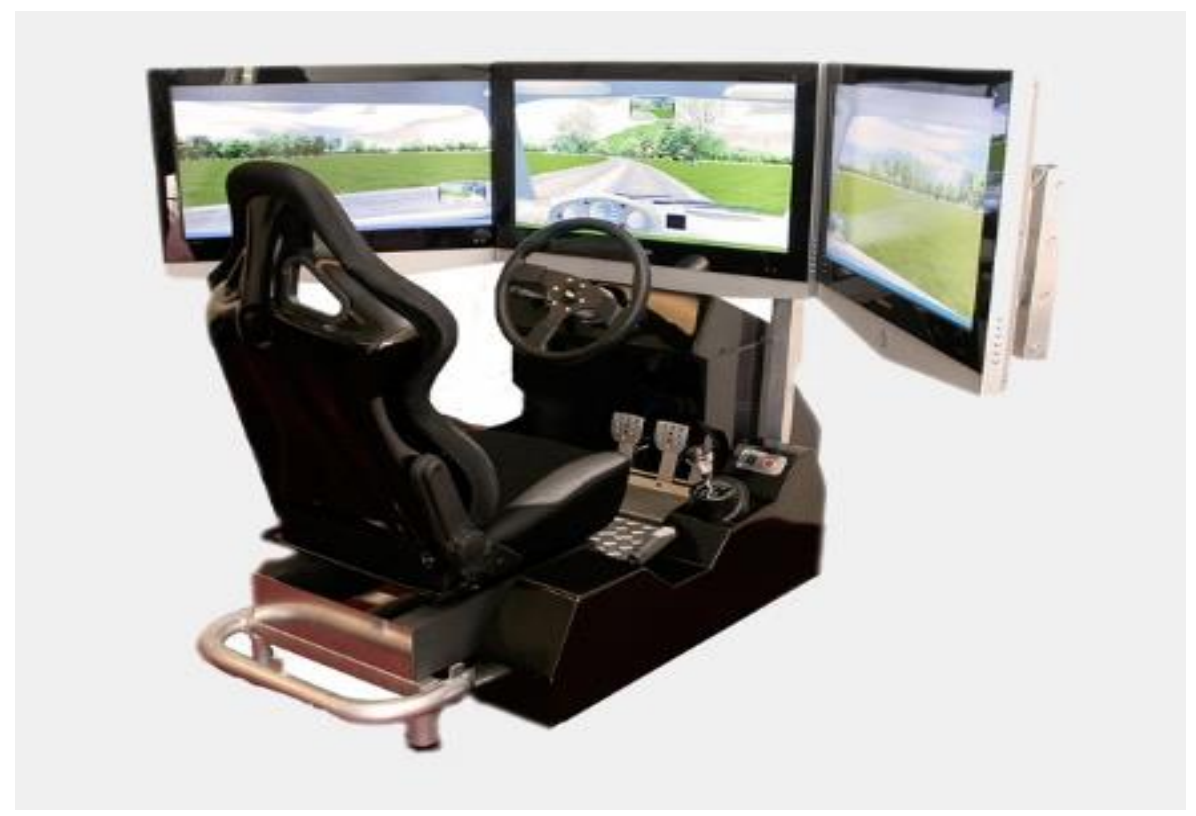

Gambar 1. Simulator Mengemudi

Setiap responden nantinya akan diberikan 2 perlakuan yang sama, yaitu melakukan simulasi menggunakan transmisi manual dan transmisi otomatis. Terkait dengan tingkat kesulitan, responden melakukan simulasi sejauh $30 \mathrm{~km}$ pada jalan yang sama dan simulasi pada kondisi jalan dan kondisi yang sudah ditentukan. Berikut merupakan spesifikasi perlakuan pada penelitian ini :

1. Responden menjalankan simulasi pada kondisi jalanan Eropa (didominasi jalanan bebas hambatan dan lurus) dengan menggunakan mobil transmisi manual dengan jarak tempuh $30 \mathrm{~km}$.

2. Responden menjalankan simulasi pada kondisi jalanan Eropa (didominasi jalanan bebas hambatan dan lurus) dengan menggunakan mobil transmisi otomatis dengan jarak tempuh $30 \mathrm{~km}$.

3. Responden menjalankan simulasi pada kondisi jalanan Sumatera (didominasi jalanan berliku, perkotaan, dan perbukitan) dengan menggunakan mobil transmisi manual dengan jarak tempuh $30 \mathrm{~km}$.

4. Responden menjalankan simulasi pada kondisi jalanan Sumatera (didominasi jalanan berliku, perkotaan, dan perbukitan) dengan menggunakan mobil transmisi otomatis dengan jarak tempuh $30 \mathrm{~km}$.
5. Responden menjalankan simulasi pada kondisi jalanan Eropa (didominasi jalanan bebas hambatan dan lurus) dengan menggunakan mobil transmisi manual dengan jarak tempuh $30 \mathrm{~km}$.

6. Responden menjalankan simulasi pada kondisi jalanan Eropa (didominasi jalanan bebas hambatan dan lurus) dengan menggunakan mobil transmisi otomatis dengan jarak tempuh $30 \mathrm{~km}$.

Simulasi pertama dan kedua ditujukan untuk mengetahui jumlah error dan waktu tempuh responden pada kondisi jalan yang sama. Simulasi ketiga dan keempat ditujukan untuk mengetahui jumlah kegagalan mengemudi pada kondisi jalanan tanjakan, kondisi jalanan turunan, dan kondisi jalanan lambat. Simulasi kelima dan keenam ditujukan untuk mengetahui jumlah kegagalan mengemudi pada kondisi jalanan cepat/ sepi. Variabel terkontrol yang ada pada penelitian ini adalah:

a. Rute, dimana pengguna dapat menentukan sendiri rute mana yang hendak dipilih dalam permainan ini.

b. Cuaca, dimana pada permainan ini pengguna dapat mengubah cuaca dengan membuka tools setting dan mengatur rain probability. 
Variabel bebas dari penelitian ini adalah segala bentuk variabel yang tidak dapat dikendalikan oleh pengguna, yaitu antara lain:

a. Waktu, dimana pada permainan ini waktu muncul secara acak pagi, siang, maupun malam.

b. Kontur jalan, dimana saat pengguna sedang menjalankan simulasi, terdapat kondisi jalan rusak ataupun yang sedang diperbaiki. c. Intensitas kendaraan, dimana jumlah kendaraan yang muncul pada permainan ini datang secara acak (generate), dapat berhenti, berakselerasi, dan melaju sesuai dengan kondisi jalan yang terjadi.

d. Marka, dimana marka jalan akan muncul mengikuti baik kondisi jalan maupun kontur jalan yang muncul saat pengguna menjalankan simulasi

Spesifikasi error yang akan dihitung selama responden melakukan simulasi, seperti terlihat pada Tabel 2.

Tabel 2. Spesifikasi Error

\begin{tabular}{|c|c|}
\hline Perlakuan & Terhitung Error Apabila \\
\hline \multirow{6}{*}{ Simulasi 1 , 3,5 (Manual) } & Responden melakukan pelanggaran lalu lintas \\
\hline & Responden menabrak kendaraan lain \\
\hline & Responden salah mengganti perseneling \\
\hline & Responden berhenti mendadak \\
\hline & Mesin mati secara tiba-tiba \\
\hline & $\begin{array}{l}\text { Responden melebihi batas kecepatan maksimal } \\
80 \mathrm{~km} / \mathrm{jam}\end{array}$ \\
\hline \multirow{4}{*}{ Simulasi 2, 4, 6 (Otomatis) } & Responden melakukan pelanggaran lalu lintas \\
\hline & Responden menabrak kendaraan lain \\
\hline & Responden berhenti mendadak \\
\hline & $\begin{array}{l}\text { Responden melebihi batas kecepatan maksimal } 80 \mathrm{~km} / \\
\text { jam }\end{array}$ \\
\hline $\begin{array}{l}\text { 3. Hasil dan Pembahasan } \\
\text { Pada penelitian ini terdapat } 6 \text { perlakuan. } 8 \text { responden } \\
\text { melakukan simulasi sejauh } 30 \mathrm{~km} \text { setiap perlakuannya, } \\
\text { dengan spesifikasi } 3 \text { perlakuan menggunakan transmisi } \\
\text { manual, dan } 3 \text { perlakuan lainya menggunakan transmisi } \\
\text { otomatis. Perlakuan } 1 \text { dan } 2 \text {, responden melakukan } \\
\text { simulasi menggunakan transmisi manual dan otomatis } \\
\text { dengan kondisi jalanan Eropa serta kondisi jalur yang } \\
\text { sama. Perlakuan } 3 \text { dan } 4 \text {, responden melakukan simulasi } \\
\text { menggunakan transmisi manual dan otomatis dengan } \\
\text { kondisi jalanan Sumatera, dengan spesifikasi kondisi } \\
\text { jalanan tanjakan, jalan turunan, dan jalan lambat. } \\
\text { Perlakuan } 5 \text { dan } 6 \text {, responden melakukan simulasi } \\
\text { menggunakan transmisi manual dan otomatis dengan }\end{array}$ & $\begin{array}{l}\text { kondisi jalanan Eropa. Hasil yang didapatkan dapat } \\
\text { dilihat pada Tabel } 3 \text {. } \\
\text { Data yang didapatkan melalui simulasi, diuji terlebih } \\
\text { dahulu menggunakan Uji Normalitas untuk mengukur } \\
\text { apakah data yang didapatkan memiliki distribusi normal. } \\
\text { Uji Normalitas yang digunakan adalah metode statistik } \\
\text { Kolmogorov Smirnov. Dari hasil rekap Sig. (2-tailed) uji } \\
\text { Kolmogorov Smirnov diketahui bahwa data hasil } \\
\text { perlakuan } 1,3,5,6 \text { berdistribusi tidak normal karena } \\
\text { memiliki Sig. (2-tailed) < 0,05, sedangkan data hasil } \\
\text { perlakuan } 2,4 \text { berdistribusi normal karena memiliki Sig. } \\
\text { (2-tailed) > 0,05. Untuk menghindari terjadinya } \\
\text { perbedaan hasil dan kesalahan pada analisis pada } \\
\text { penelitian ini, akandigunakan uji statistik non-parametrik }\end{array}$ \\
\hline
\end{tabular}


pada seluruh data hasil perlakuan dengan metode Wilcoxon seperti terlihat pada Tabel 4.

Dari hasil rekapitulasi diketahui bahwa hanya ada dua perlakuan yang hasilnya berpengaruh signifikan yaitu pengaruh transmisi terhadap terjadinya error mengemudi dan pengaruh transmisi terhadap terjadinya kegagalan mengemudi pada kondisi jalan tanjakan. Perlakuan lainya tidak berpengaruh signifikan antara transmisi dan perlakuan yang diberikan.

\subsection{Analisis Pengaruh Transmisi Terhadap Terjadinya Error Mengemudi}

Sheila (2014) menjelaskan bahwa semakin banyak pekerjaan yang dilakukan saat mengemudi dalam satu waktu oleh pengemudi pemula lebih beresiko mengalami kecelakaan di jalan dibandingkan dengan pengemudi berpengalaman. Sejalan dengan hasil tersebut, penelitian ini menunjukan bahwa transmisi manual menimbulkan terjadinya error yang lebih banyak dibandingkan transmisi otomatis.

Tabel 3. Rekap Hasil Penelitian

\begin{tabular}{|c|c|c|c|c|c|c|c|c|c|c|c|c|}
\hline \multirow{3}{*}{ No. } & \multirow{2}{*}{\multicolumn{2}{|c|}{ Error }} & \multirow{2}{*}{\multicolumn{2}{|c|}{$\begin{array}{l}\text { Waktu Tempuh } \\
\text { (detik) }\end{array}$}} & \multicolumn{8}{|c|}{ Kegagalan Mengemudi } \\
\hline & & & & & \multicolumn{2}{|c|}{$\begin{array}{c}\text { Kondisi Jalan } \\
\text { Tanjakan }\end{array}$} & \multicolumn{2}{|c|}{$\begin{array}{l}\text { Kondisi Jalan } \\
\text { Turunan }\end{array}$} & \multicolumn{2}{|c|}{$\begin{array}{c}\text { Kondisi Jalanan } \\
\text { Cepat }\end{array}$} & \multicolumn{2}{|c|}{$\begin{array}{c}\text { Kondisi Jalanan } \\
\text { Lambat }\end{array}$} \\
\hline & Manual & Otomatis & Manual & Otomatis & Manual & Otomatis & Manual & Otomatis & Manual & Otomatis & Manual & Otomatis \\
\hline 1 & 5 & 4 & 486 & 549 & 3 & 3 & 2 & 3 & 4 & 6 & 2 & 3 \\
\hline 2 & 8 & 4 & 640 & 552 & 3 & 2 & 2 & 4 & 6 & 6 & 3 & 2 \\
\hline 3 & 9 & 3 & 542 & 557 & 4 & 2 & 4 & 3 & 6 & 5 & 3 & 2 \\
\hline 4 & 7 & 5 & 620 & 472 & 3 & 1 & 4 & 2 & 6 & 4 & 3 & 2 \\
\hline 5 & 5 & 5 & 600 & 544 & 4 & 0 & 5 & 4 & 5 & 4 & 4 & 4 \\
\hline 6 & 8 & 4 & 579 & 492 & 5 & 4 & 3 & 3 & 4 & 5 & 3 & 2 \\
\hline 7 & 8 & 5 & 490 & 481 & 3 & 3 & 3 & 3 & 5 & 5 & 3 & 3 \\
\hline 8 & 5 & 5 & 615 & 495 & 3 & 1 & 2 & 1 & 4 & 4 & 4 & 3 \\
\hline Total & 55 & 35 & 4572 & 4142 & 28 & 16 & 25 & 23 & 40 & 39 & 25 & 21 \\
\hline $\begin{array}{l}\text { Rata- } \\
\text { rata }\end{array}$ & 6,875 & 4,375 & 571,5 & 517,75 & 3,5 & 2 & 3,125 & 2,875 & 5 & 4,875 & 3,125 & 2,625 \\
\hline
\end{tabular}

Tabel 4. Rekap Uji Wilcoxon

\begin{tabular}{lcc}
\hline \multicolumn{1}{c}{ Uji Wilcoxon } & $\begin{array}{c}\text { sig. } 2 \\
\text { tailed }\end{array}$ & Hasil \\
\hline Pengaruh transmisi terhadap terjadinya error mengemudi & 0,027 & tolak H0 \\
\hline Pengaruh transmisi terhadap lamanya waktu mengemudi & $0,093 \quad$ terima H0 \\
\hline Pengaruh transmisi terhadap terjadinya kegagalan mengemudi pada kondisi jalan tanjakan & $0,026 \quad$ tolak H0 \\
\hline Pengaruh transmisi terhadap terjadinya kegagalan mengemudi pada kondisi jalan turunan & 0,589 & terima H0 \\
\hline Pengaruh transmisi terhadap terjadinya kegagalan mengemudi pada kondisi jalanan cepat & $0,783 \quad$ terima H0 \\
\hline Pengaruh transmisi terhadap terjadinya kegagalan mengemudi pada kondisi jalanan lambat & 0,102 & terima H0 \\
\hline
\end{tabular}


Tidak banyak penyebab teknis yang memicu terjadinya error pada simulasi 1 dan 2, hanya beberapa responden yang melakukan kesalahan teknis seperti salah memindahkan perseneling yang berakibat mesin mati pada saat melakukan simulasi menggunakan transmisi manual. Sebagian besar error yang tercatat umumnya dikarenakan responden melanggar batas kecepatan maksimal yaitu $80 \mathrm{~km} /$ jam dan melanggar marka jalan. Hal tersebut cenderung tidak disadari oleh responden, dikarenakan kondisi jalan pada perlakuan 1 didominasi oleh jalanan bebas hambatan dan lurus.

Faktor lain penyebab banyaknya error yang terjadi adalah karena informasi dari peneliti kepada responden pada saat pilot study bahwa akan dilakukan perhitungan lamanya waktu pada simulasi 1 dan 2 . Hal tersebut berpotensi memicu responden untuk mengemudi dengan cepat. Penyebab lain terkait dengan gender responden dalam penelitian ini yang didominasi oleh responden pria. Penelitian sebelumnya oleh Massie, dkk (1995) menyatakan bahwa pria lebih sering terlibat kecelakaan yang diakibatkan melanggar batas kecepatan. Hal ini sejalan dengan hasil yang didapatkan, dimana gaya mengemudi laki - laki yang cenderung ceroboh (reckless) dapat meningkat sejalan dengan kondisi jalan yang dihadapi.

\subsection{Analisis Pengaruh Transmisi Terhadap Lamanya Waktu Mengemudi}

Hasil yang didapatkan pada perlakuan ini tidak sejalan dengan hasil penelitian yang dilakukan oleh Grisnhpan (2011) yang menjelaskan bahwa akselerasi yang diciptakan transmisi manual lebih tinggi dibandingkan transmisi otomatis. Waktu tempuh mengemudi yang dihasilkan transmisi manual lebih cepat dibandingkan transmisi otomatis. Hasil yang didapatkan pada penelitian ini menunjukan bahwa perolehan waktu transmisi manual lebih lama dibandingkan dengan transmisi otomatis. Selisih rata-rata perbedaan waktu antara transmisi manual dan otomatis tidak terlalu besar, dikarenakan kondisi jalan pada saat simulasi didominasi jalan bebas hambatan dan lurus. Sejalan dengan hasil rata-rata perhitungan error pada Tabel 3, perolehan waktu pada saat simulasi menggunakan transmisi manual lebih besar dikarenakan responden lebih sering melakukan error pada transmisi ini.

Seperti yang dijelaskan pada latar belakang penelitian ini, transmisi manual lebih sulit dalam pengoperasianya terbukti pada saat melakukan simulasi menggunakan transmisi manual responden lebih sering melakukan kesalahan yang berakibat perolehan waktu mengemudi lebih besar dibandingkan saat responden melakukan simulasi menggunakan transmisi otomatis.

\subsection{Analisis Pengaruh Transmisi Terhadap Kegagalan Mengemudi Pada Kondisi Jalan Tanjakan}

Dari hasil yang didapatkan, diketahui bahwa jumlah kegagalan mengemudi pada simulasi menggunakan transmisi mobil manual lebih besar dibandingkan dengan transmisi otomatis. Kondisi jalan tanjakan merupakan track yang sulit untuk pengemudi pemula. Umumnya kegagalan mengemudi pada transmisi manual yang dilakukan oleh responden adalah mesin mati mendadak, mobil mundur ke belakang yang berakibat pada menabrak kendaraan lain.

Bagi pengemudi pemula, penggunaan kopling pada transmisi manual menjadi penyebab utama mereka melakukan kegagalan mengemudi, atensi harus terbagi lebih banyak. Berbeda dengan kegagalan mengemudi pada transmisi otomatis yang umumnya dikarenakan responden kehilangan kontrol pada mobilnya, kecepatan yang terlalu tinggi pada jalan tanjakan menyebabkan responden menabrak kendaraan yang berada di depannya. Hal tersebut terjadi dikarenakan pengoperasian mobil transmisi otomatis lebih praktis, namun apabila tidak sejalan dengan kewaspadaan, akan berakibat kecelakaan lalu lintas.

\subsection{Analisis Pengaruh Transmisi Terhadap Kegagalan Mengemudi Pada Kondisi Jalan Turunan}

Dari hasil yang didapatkan, diketahui bahwa jumlah kegagalan mengemudi pada simulasi menggunakan transmisi mobil manual lebih besar dibandingkan dengan transmisi otomatis. Kondisi jalan turunan merupakan track yang sulit untuk pengemudi pemula. Umumnya kegagalan mengemudi pada transmisi manual yang dilakukan oleh responden adalah mesin mati mendadak, mobil maju dengan sendirinya yang berakibat pada menabrak kendaraan lain. Bagi pengemudi pemula, penggunaan hand rem tentunya belum tentu diperhatikan, namun pada kondisi jalan turunan hand rem menjadi komponen utama untuk menjaga kontrol mobil. Selain itu bagi pengemudi pemula, penggunaan kopling pada transmisi manual menjadi penyebab utama mereka melakukan kegagalan mengemudi, atensi harus terbagi lebih banyak.

Berbeda dengan kegagalan mengemudi pada transmisi otomatis yang umumnya dikarenakan responden kehilangan kontrol pada mobil nya, kecepatan yang terlalu tinggi pada jalan turunan menyebabkan responden menabrak kendaraan yang berada di depannya. Hal tersebut terjadi dikarenakan pengoperasian mobil transmisi otomatis lebih praktis, namun apabila tidak sejalan dengan kewaspadaan, akan berakibat kecelakaan lalu lintas. 


\subsection{Analisis Pengaruh Transmisi Terhadap Kegagalan Mengemudi Pada Kondisi Jalan Cepat}

Pada penelitian sebelumnya oleh Ronghua Wang, dkk. (2016) dijelaskan bahwa perilaku pengemudi yang berkendara pada jalan bebas hambatan cenderung kurang waspada. Faktor jalan yang luas dan arus lalu lintas yang sepi justru menambah tingkat bahaya terjadinya kecelakaan. Dari hasil yang didapatkan, diketahui bahwa jumlah kegagalan mengemudi pada simulasi menggunakan transmisi mobil manual lebih besar dibandingkan dengan transmisi otomatis. Kebanyakan responden melakukan kesalahan mendasar seperti melanggar lalu lintas, dan melanggar batas kecepatan 80 $\mathrm{km} / \mathrm{jam}$. Hal tersebut terjadi dikarenakan pada perlakuan ini responden mengemudi pada kondisi jalan yang didominasi jalan bebas hambatan dan lurus. Oleh karena itu responden cenderung tidak menyadari apabila melebihi batas kecepatan yang ditentukan.

Kegagalan mengemudi pada transmisi manual lebih banyak dikarenakan terjadi kendala teknis pada beberapa responden. Umumnya kendala teknis yang terjadi adalah salah mengganti perseneling dan mesin mati secara mendadak. Pada transmisi otomatis, kegagalan mengemudi yang terjadi merupakan pelanggaranpelanggaran lalu lintas. Beberapa respoden mengalami kecelakaan yang dikarenakan tidak menyadari apabila kecepatan mobil terlalu tinggi, akibatnya kondisi mobil menjadi tidak terkontrol dan menabrak mobil lain yang hendak menyalip mobil responden.

\subsection{Analisis Pengaruh Transmisi Terhadap Kegagalan Mengemudi Pada Kondisi Jalanan Lambat}

Dari hasil yang didapatkan, diketahui bahwa jumlah kegagalan mengemudi pada simulasi menggunakan transmisi mobil manual lebih besar dibandingkan dengan transmisi otomatis. Pada kondisi jalanan lambat, kegagalan mengemudi yang terjadi umumnya dikarenakan responden menabrak kendaraan lain, dikarenakan pada perlakuan ini kondisi jalan didominasi jalanan berkelok ditambah dengan kondisi lalu lintas yang padat. Oleh karena itu responden cenderung tidak sabar sehingga berusaha menyalip kendaraan yang berada di depanya.

Pada simulasi menggunakan transmisi manual, dikarenakan kecepatan mobil tidak stabil dikarenakan kondisi jalanan yang padat, berakibat pada terjadinya kesalahan teknis dalam pengoperasiannya hal tersebut merupakan penyebab mengapa kegagalan mengemudi pada transmisi manual lebih banyak. Sedangkan pada transmisi otomatis kegagalan mengemudi yang terjadi umumnya dikarenakan responden melanggar peraturan lalu lintas, seperti melanggar marka dan menerobos lalu lintas.

\section{Kesimpulan}

Dari serangkaian hasil penelitian, dapat disimpulkan bahwa berdasarkan 6 perlakuan yang diberikan kepada 8 responden didapatkan hasil bahwa 2 perlakuan menunjukan transmisi mobil berpengaruh signifikan terhadap terjadinya error mengemudi dan kondisi jalan tanjakan, sedangkan 4 perlakuan lainya menunjukan transmisi mobil tidak berpengaruh signifikan terhadap lamanya waktu mengemudi, kondisi jalanan turunan, kondisi jalanan cepat, dan kondisi jalanan lambat.

Hasil total error pada perlakuan 1 transmisi manual adalah sebesar 55 dengan rata-rata 6,875, dan transmisi otomatis sebesar 35 dengan rata-rata 4,375. Hasil total lamanya waktu mengemudi pada perlakuan 2 transmisi manual adalah sebesar 4.572 detik dengan rata-rata 571,5 , dan transmisi otomatis sebesar 4.142 detik dengan ratarata 517,75. Hasil total kegagalan mengemudi pada kondisi jalanan tanjakan transmisi manual adalah sebesar 28 dengan rata-rata 3,5, dan transmisi otomatis sebesar 16 dengan rata-rata 2 . Hasil total kegagalan mengemudi pada kondisi jalanan turunan transmisi manual adalah sebesar 25 dengan rata-rata 3,125, dan transmisi otomatis sebesar 23 dengan rata-rata 2,875. Hasil total kegagalan mengemudi pada kondisi jalanan cepat transmisi manual adalah sebesar 40 dengan rata-rata 5 , dan transmisi otomatis sebesar 39 dengan rata-rata 4,875. Hasil total kegagalan mengemudi pada kondisi jalanan lambat transmisi manual adalah sebesar 25 dengan rata-rata 3,125 , dan transmisi otomatis sebesar 21 dengan rata-rata 2,625 .

Rekomendasi transmisi mobil yang lebih baik terkait dengan keamanan berkendara bagi pengemudi pemula untuk mengemudi pada kondisi jalan yang didominasi jalan bebas hambatan dan lurus adalah transmisi otomatis. Transmisi mobil yang lebih baik terkait dengan keamanan bagi pengemudi pemula untuk mengemudi pada kondisi jalan perbukitan yang didominasi tanjakan, turunan, dan cenderung padat kendaraan adalah transmisi otomatis. Transmisi otomatis dinilai lebih baik dalam meningkatkan keamanan berkendara bagi pengemudi pemula, dikarenakan pada proses belajar hal penting yang harus diperhatikan adalah seberapa banyak pekerjaan yang harus dilakukan dalam satu waktu. Pada transmisi otomatis, atensi yang terbagi saat mengemudi tidak lebih banyak dibandingkan transmisi manual. Transmisi manual secara teknis lebih sulit dioperasikan.

Penggunaan kopling dan hand rem yang tidak tepat justru membahayakan pengemudi pemula. Hal ini terlihat pada total kesalahan yang dilakukan oleh responden pada saat simulasi transmisi manual lebih banyak dibanding transmisi otomatis. Umumya kesalahan yang terjadi merupakan kesalahan teknis yang berakibat kecelakaan lalu lintas. 


\section{Daftar Pustaka}

Beirness, D.J., Simpson, H.M. dan Desmond, K. 2002. The Road Safety Monitor 2002 Risky Driving. Traffic Injury Research Foundation. Ottawa, Ontario.

Daryanto. 2001. Evaluasi Mengemudi. Jakarta: PT. Rineka Cipta.

Falkmer, T., Selander, H., Bolin, I. 2008. Why drive manual? - Automatic transmission improves driving behavior in older drivers. School of Health Sciences, Jonkoping University. Sweden.

Grisnhpan, A. 2011. Comparison of First Gear Performance for Manual and Automatic Transmissions. University of South Florida. USA.

Hale, A.R. dan Glendon, I. 1987. Individual Behaviour in the Control of Danger. Elsevier Publishing Company. USA.

Lim, S. 2009. Safety Driving Guidance Book. Bogor: Halaman Moeka.

Massie, D L., Campbell KL, Williams AF. 1995. Traffic Accident Involvement Rates By Driver Age And
Gender. Insurance Institute for Highway Safety. USA.

Mogre, M.R. 2012. Comparative Study between Automatic and Manual Transmission Car. Proceeding of International Conference on Mechanical, Automobile and Biodiesel Engineering (ICMABE'2012). Oct. 6-7, 2012 Dubai (UAE).

Klauer, S.G. Guo, F., Simons-Morton, B.G., Ouimet, M.C., Lee, S.E. dan Dingus, T.A. 2014. Distracted Driving and Risk of Road Crashes among Novice and Experienced Drivers. N Engl J Med 2014; 370:54-59. January 2, 2014

Stottlemyer, K. 2011. Comparison of First Gear Performance for Manual and Automatic Transmissions. University of South Florida.

Wang, R., Jiangbi, H, dan Xiaoqin, Z. 2016. Analysis of the Driver's Behavior Characteristics in Low Volume Freeway Interchange. Mathematical Problems in Engineering. Vol. 2016 (2016), Article ID 2679516. 